\title{
PYXILORICARIA MENEZESI, A NEW GENUS AND SPECIES OF MAILED CATFISH FROM RIO MIRANDA AND RIO CUIABÁ, BRAZIL (PISCES, SILURIFORMES, LORICARIIDAE)
}

\author{
by \\ I. J. H. ISBRÜCKER \& H. NIJSSEN \\ Institute of Taxonomic Zoology, University of Amsterdam, \\ P.O. Box 20125, 1000 HC Amsterdam, The Netherlands
}

\begin{abstract}
SUMMARY
Pyxiloricaria menezesi n. gen., n. sp., is described and illustrated from Rio Miranda (Est. Mato Grosso do Sul) and from Rio Cuiabá (Est. Mato Grosso), Brazil. It is assigned to the subtribe Planiloricariina of the tribe Loricariini, subfamily Loricariinae. A comparison is made with sympatric Pseudohemiodon cf. laticeps (Regan, 1904).

\section{RÉSUMÉ}

On donne une description illustrée de Pyxiloricaria menezesi n. gen., n. sp., du Rio Miranda (Est. Mato Grosso do Sul) et du Rio Cuiabá (Est. Mato Grosso), Brésil. La nouvelle espèce appartient à la sous-tribu Planiloricariina (tribu Loricariini, sous-famille Loricariinae). On la compare avec Pseudohemiodon cf. laticeps (Regan, 1904), espèce sympatrique avec celle nouvelle.
\end{abstract}

\section{INTRODUCTION}

While visiting the Museu de Zoologia da Universidade de São Paulo (MZUSP) and the Universidade Federal de São Carlos (UFSCAR), Estado de São Paulo, Brazil, the first author encountered an undescribed species of the subfamily Loricariinae. It is herein described as a new genus and species, Pyxiloricaria menezesi. The genus shows a superficial similarity to Pseudohemiodon Bleeker, 1862, which, together with four other genera has been assigned to the subtribe Planiloricariina, tribe Loricariini (Martín Salazar et al., 1982).

We are grateful to Dr. J. C. Garavello (UFSCAR), who participated in collecting the holotype and a paratype of Pyxiloricaria menezesi, and to Dr. H. A. Britski (MZUSP) for the loan of the material. Mr. L. A. van der Laan of the Zoölogisch Museum, Amsterdam (ZMA) made the photographs.
Financial support for the visit to Brazil (January 1983) was given to the first author by the Treub Society for Tropical Research (Utrecht), the Artis Fund (Amsterdam), and the Royal Academy of Sciences of the Netherlands (Amsterdam).

\section{Pyxiloricaria n. gen.}

Type-species. - Pyxiloricaria menezesi n. sp.

Etymology. - From the Latin pyxis meaning box (an allusion to the distinctive body shape, which is trapezoid in a transverse section along the coalescing lateral body scutes), and from Loricaria, type-genus of the family Loricariidae.

Pyxiloricaria is assigned to the subtribe Planiloricariina, tribe Loricariini of the subfamily Loricariinae (cf. Martín Salazar et al., 1982), hitherto comprising the genera Pseudohemiodon Bleeker, 1862, Planiloricaria Isbrücker, 1971, Rhadinoloricaria Isbrücker \& Nijssen, 1974, Crossoloricaria Isbrücker, 1979, and Dentectus Martín Salazar, Isbrücker \& Nijssen, 1982.

It differs from all these genera (as well as from all other genera of the subfamily Loricariinae) by the peculiar shape of head, body and fins (figs. 1-4). Pyxiloricaria has large, broad pectoral fins (pectoral fin spine 3.9-4.5 times in standard length, rarely 4.5 , usually 5.0-6.6 in other Planiloricariina), and a low number of lateral body scutes (29-30, against $31-40$ in the other genera of Planiloricariina).

Fin ray counts: dorsal $\mathrm{I}, 6, \mathrm{i}$; anal $\mathrm{I}, 4, \mathrm{i}$; pectoral I,6; pelvic I,5; caudal I,10,I. 


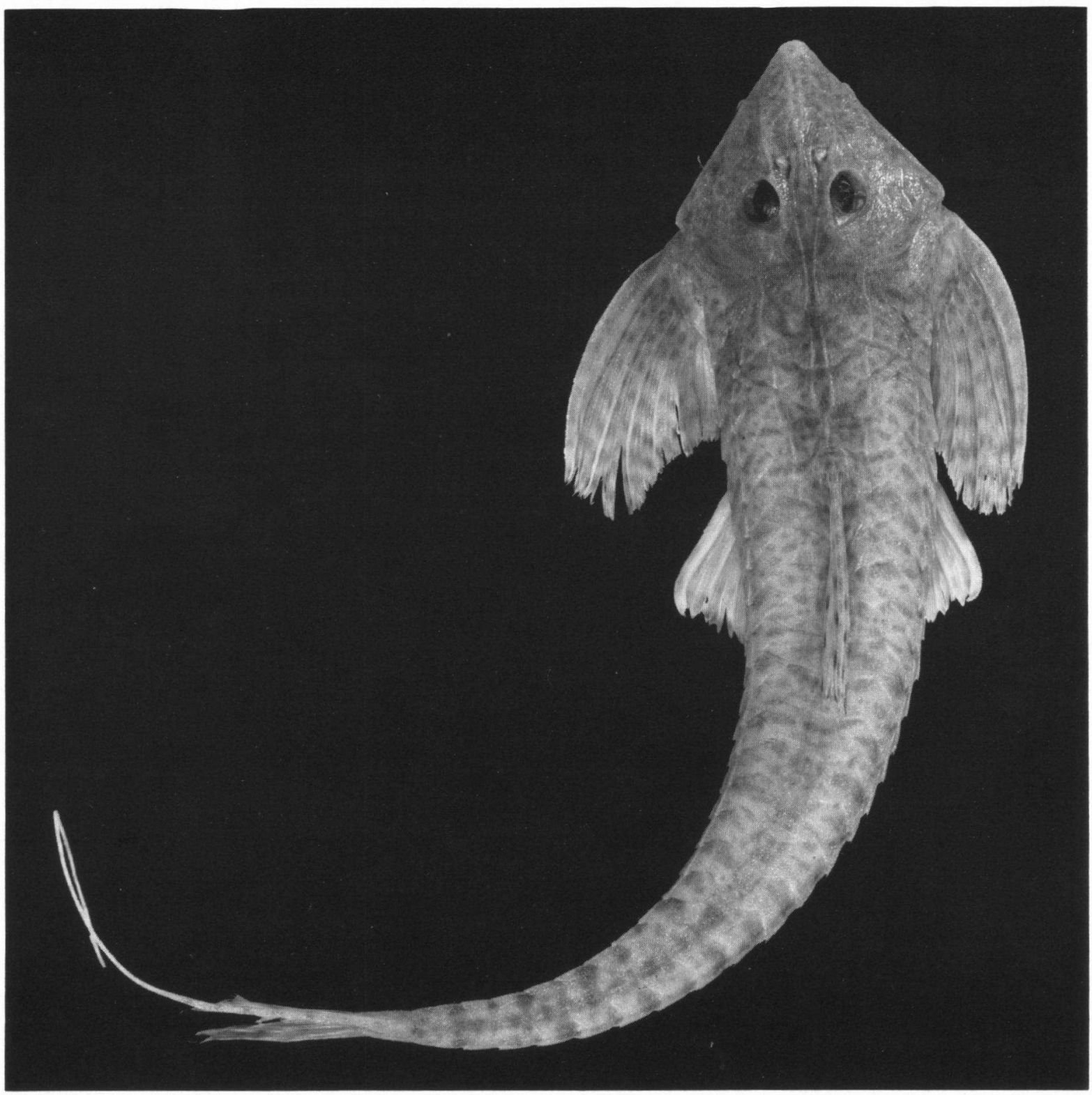

Fig. 1. Pyxiloricaria menezesi n. gen., n. sp., holotype in dorsal view.

Further characters are given in the description of the single species included in Pyxiloricaria:

\section{Pyxiloricaria menezesi n. sp.}

(Figs. 1-4; table I)

Material. - Holotype, MZUSP 26800, standard length $136 \mathrm{~mm}$; paratype, ZMA 107.890, standard length 90.1 mm, Brazil, Est. Mato Grosso do Sul, "Lagoas marginais da rodovia Transpantaneira, município de Miranda" $\left(20^{\circ} 10^{\prime} \mathrm{S} 56^{\circ} 19^{\top} \mathrm{W}\right)$, coll. J. C. Garavello and party (Eq. Ict. DCB-UFSCAR), 8/22-XI-1981; paratype, MZUSP 24860, standard length $105.3 \mathrm{~mm}$, Brazil, Est. Mato Grosso, Rio Cuiabá, at ca. $3 \mathrm{~km}$ from Santo Antônio do Leverger $\left(15^{\circ} 52^{\prime} \mathrm{S} 56^{\circ} 05^{\prime} \mathrm{W}\right)$, coll. CEPIPAM, 28-VIII-1976.

Etymology. - Named in honour of Dr. Naercio A. Menezes, MZUSP, in recognition of his friendly support and hospitality during the first author's stay in Brazil. 
Description. - Morphometric and meristic data (taken according to the methods described by Isbrücker \& Nijssen, 1978: 180-182) are given in table I. Figs. 1-4 illustrate the holotype.

Holotype: Preanal plate absent. There is a narrow median, mostly double row of irregular polygonal scutelets anterior to the anus (which is surrounded by a small, triangular naked area). These scutelets reach similar small scutelets within the area between the posterior three thoracic scutes. Anterior to these scutelets, the abdomen is partially covered with scutelets, isolated by naked skin from the thoracic scutes; the scutelets continue between the pectoral fin origin as shown in fig. 4 .

Ventral surface of head naked, except for a marginal series of somewhat rectangular dermal ossifications. A large, transverse, fleshy wrinkled flap originates from the anterior margin of the branchiostegal membrane, covering about half of this membrane.

Upper lip preceded by a naked area, continuing anteriorly into the notched ventrorostral ossification. Upper lip narrow, with six or seven simple barbels along or near the edge at either side. Premaxillae surrounded by three series of slender, simple barbels (ignoring a minute protuberance at one barbel), a longitudinal trifid barbel at the symphysis of the jaws, and a transverse series of three barbels at either side.

Maxillary barbel free from margin of snout, embedded into a groove. The barbel has six subbarbels. Except for the barbels, the ventral surface of the upper lip and the connecting area towards the maxillary barbel origin is smooth. Lower lip close-set with short, smooth barbels, decreasing in length towards the posterior margin, which itself is almost smooth, irregular, bearing a few minute barblets only. Mandibulae surrounded by few, slender barblets and by a wide naked area; in front of the numerous simple barbels on the lower lip are a few bifid and trifid barbels.

Pectoral fin spine rather broad, dorsally and ventrally flattened. Pectoral fin rays proximally broad, the third ray being the broadest at its tip with distally eight branches.

\section{TABLE I}

Morphometric and meristic data of Pyxiloricaria menezesi $n$. gen., n. sp.: (A), data of holotype in $\mathrm{mm}$; A, holotype; B, paratype MZUSP 24860; C, paratype ZMA 107.890. Standard length through total length in $\mathrm{mm}$. In columns A-C, head length through lower caudal spine length are expressed as ratios of standard length, snout length through width caudal peduncle are expressed as ratios of head length.

\begin{tabular}{|c|c|c|c|c|}
\hline specimens & (A) & A & B & C \\
\hline standard length & 136.0 & 136.0 & 105.3 & 90.1 \\
\hline axial length & 153.8 & 153.8 & 118.6 & 102.5 \\
\hline total length & $>228.6$ & $>228.6$ & 230.7 & 201.5 \\
\hline head length & 30.4 & 4.5 & 4.5 & 4.2 \\
\hline predorsal length & 45.6 & 3.0 & 3.1 & 2.9 \\
\hline postdorsal length & 75.3 & 1.8 & 1.8 & 1.9 \\
\hline postanal length & 60.1 & 2.3 & 2.2 & 2.3 \\
\hline dorsal spine length & 28.3 & 4.8 & 4.9 & $<5.2$ \\
\hline \multicolumn{5}{|l|}{ first dorsal ray } \\
\hline length & 26.7 & 5.1 & 5.2 & 4.5 \\
\hline anal spine length & 21.8 & 6.2 & 6.8 & 5.3 \\
\hline pectoral spine length & 30.4 & 4.5 & - & 3.9 \\
\hline pelvic spine length & 18.8 & 7.2 & 6.4 & 6.6 \\
\hline \multicolumn{5}{|l|}{ upper caudal spine } \\
\hline length & $>92.6$ & $<1.5$ & 0.8 & 0.8 \\
\hline \multicolumn{5}{|l|}{ lower caudal spine } \\
\hline length & 23.4 & 5.8 & $<5.8$ & $<7.2$ \\
\hline snout length & 17.2 & 1.8 & 1.8 & 1.8 \\
\hline ventrorostral length & 2.8 & 10.9 & 18.0 & 13.4 \\
\hline lower lip & 6.9 & 4.4 & 4.4 & 4.9 \\
\hline maxillary barbel & 11.3 & 2.7 & 2.7 & 2.2 \\
\hline thoracic length & 27.7 & 1.1 & 1.1 & 1.2 \\
\hline abdominal length & 25.9 & 1.2 & 1.3 & 1.4 \\
\hline \multicolumn{5}{|l|}{ maximum orbital dia- } \\
\hline meter & 6.5 & 4.7 & 4.4 & 4.9 \\
\hline interorbital width & 5.2 & 5.9 & 6.5 & 6.1 \\
\hline cleithral width & 32.4 & 0.9 & 1.0 & 1.0 \\
\hline supracleithral width & 19.7 & 1.5 & 1.6 & 1.6 \\
\hline head width & 29.8 & 1.0 & 1.0 & 1.0 \\
\hline head depth & 11.7 & 2.6 & 2.7 & 2.5 \\
\hline body depth at dorsal & 13.3 & 2.3 & 2.4 & 2.5 \\
\hline body width at dorsal & 22.6 & 1.4 & 1.4 & 1.6 \\
\hline body width at anal & 18.0 & 1.7 & 1.7 & 1.8 \\
\hline depth caudal peduncle & 2.5 & 12.2 & 13.0 & 13.4 \\
\hline width caudal peduncle & 4.0 & 7.6 & 6.9 & 6.9 \\
\hline lateral scutes & - & $30 / 30$ & $30 / 29$ & $29 / 29$ \\
\hline coalescing scutes & 一 & $20 / 20$ & $17 / 17$ & $18 / 18$ \\
\hline thoracic scutes & 一 & $7 / 7$ & $7 / 7$ & $7 / 6$ \\
\hline premaxillary teeth & - & $2 / 3$ & $3 ? / 3 ?$ & $2 ? / 2$ \\
\hline dentary teeth & - & $2 / 3$ & ?/? & $3 / 2$ \\
\hline
\end{tabular}

Tip of snout covered with odontodes. Thoracic scutes touching the inner pectoral fin 
I. J. H. ISBRÜCKER \& H. NIJSSEN - PYXILORICARIA MENEZESI N. G., N. SP.

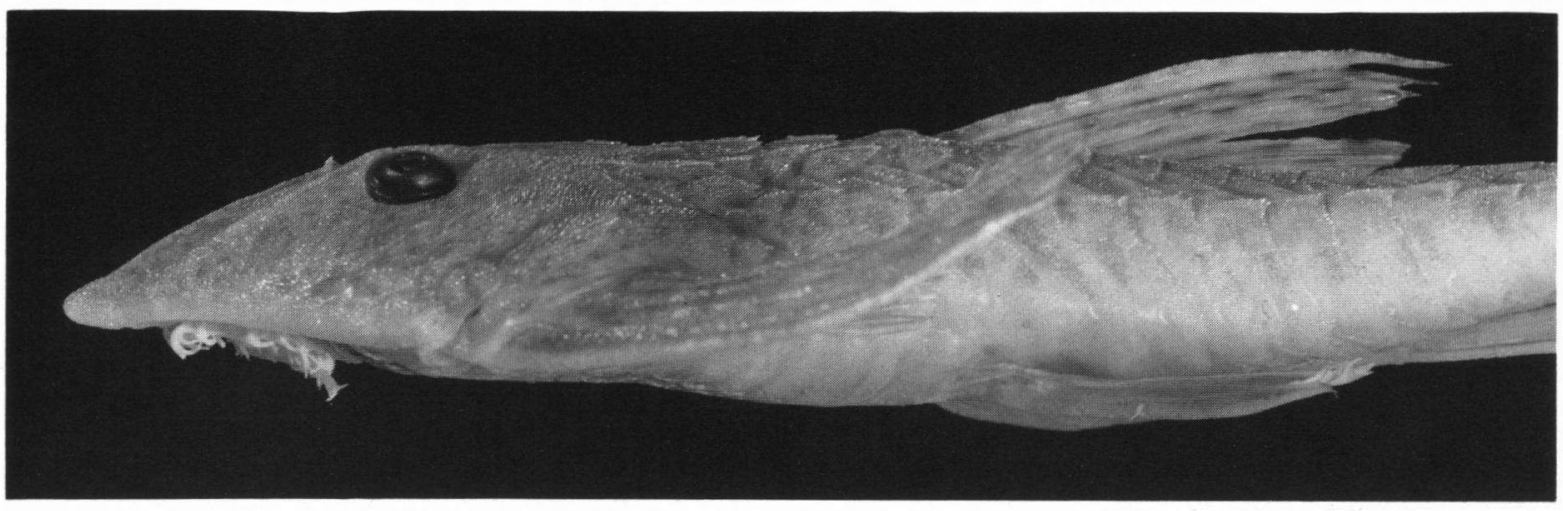

Fig. 2. Pyxiloricaria menezesi n. gen., n. sp., holotype in lateral view.

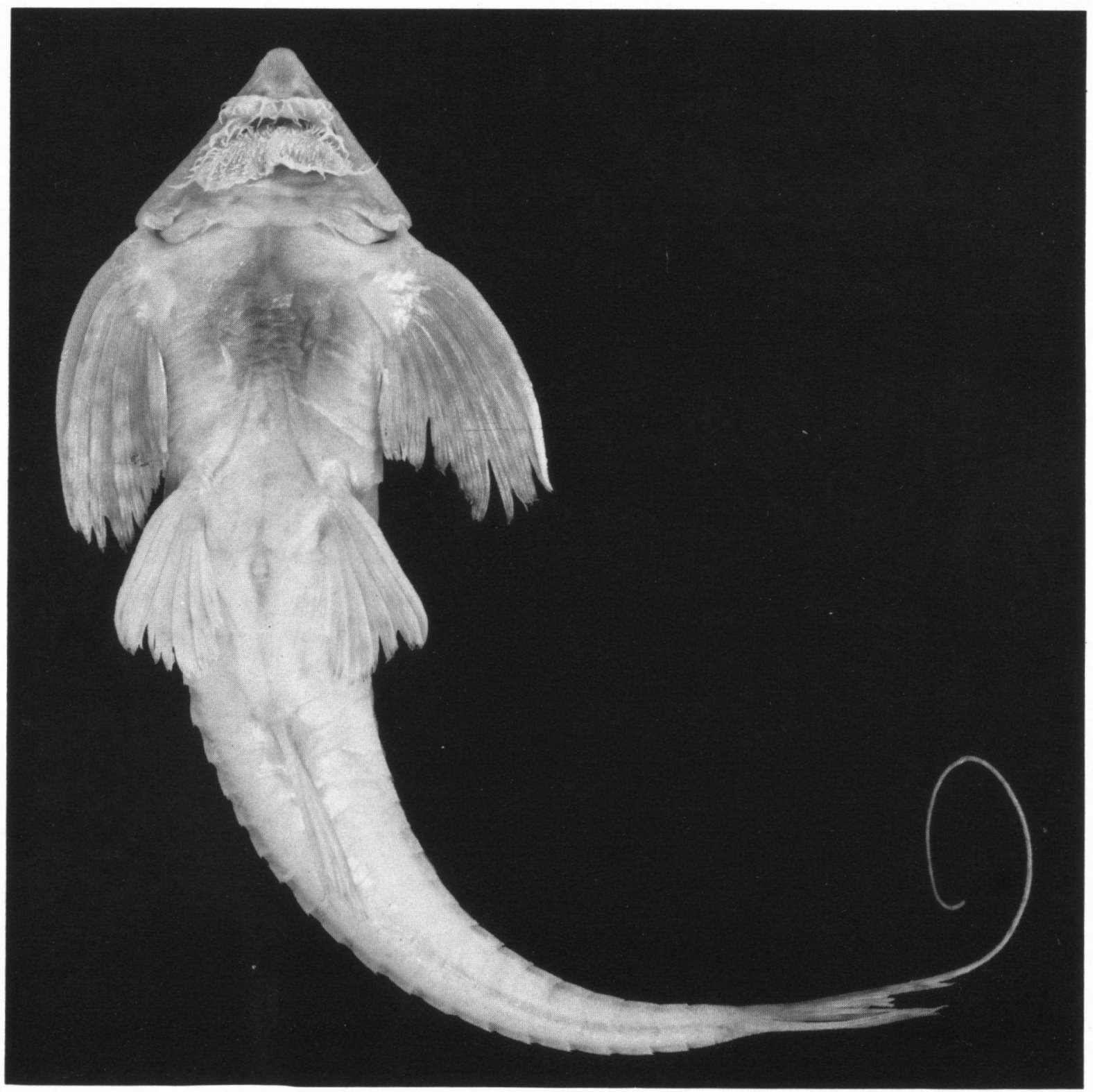

Fig. 3. Pyxiloricaria menezesi n. gen., n. sp., holotype in ventral view. 

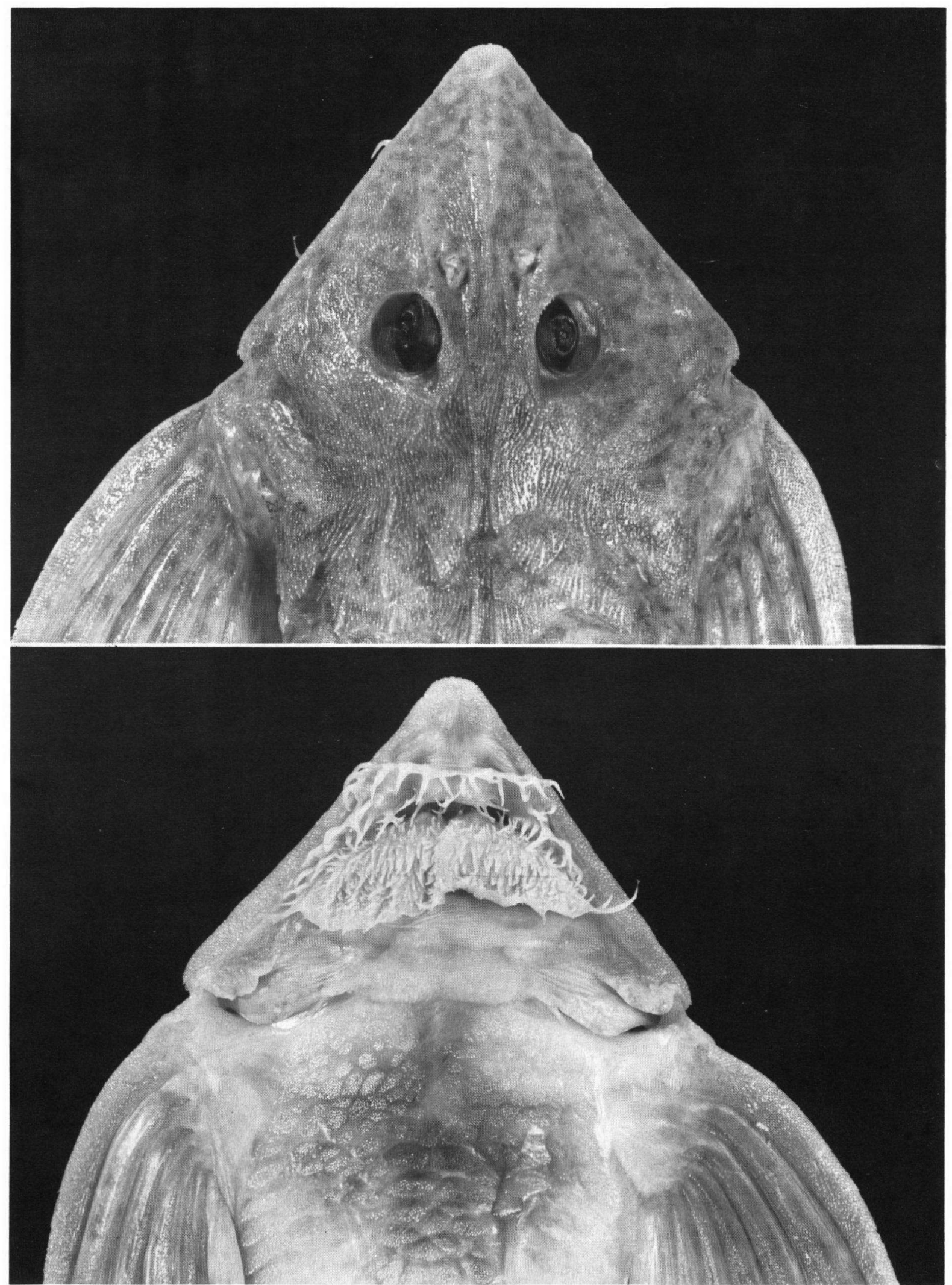

Fig. 4. Pyxiloricaria menezesi n. gen., n. sp., detail of head of holotype in dorsal and ventral view. 
ray with a narrow horizontal strip devoid of odontodes. There are no odontodes on the scutes covered by the last pelvic fin ray and along the base of the anal fin.

Pectoral pore not visible. Sensory canal system inconspicuous.

Orbital rim oval, with a continuous small anterior notch, a narrow lateroventral naked strip, and a larger posterior notch.

Teeth hard to observe: small, simple, with a broad rounded crown.

Colour in alcohol (figs. 1-4). - Ground colour beige. Dorsum and sides with faint greyish brown pigment, as shown in the illustrations.

Paratypes: Essentially as the holotype, having less numerous and smaller abdominal scutelets. As shown in table I, some morphometric characters are quite different (e.g., length first dorsal fin ray, anal fin spine length, pectoral fin spine length, pelvic fin spine length, maximum orbital diameter, and interorbital width). With only three specimens - from two localities available, it is difficult to explain these differences.

Comparison. - Pyxiloricaria menezesi was collected at its type-locality together with 98 specimens of a Pseudohemiodon species, which we tentatively identify as $P$. laticeps (Regan, 1904) (eight specimens in MZUSP 26802, six in ZMA 107.889, the remaining ones in UFSCAR).
Both species resemble each other superficially. At this point we think it to be sufficient to mention only the most obvious differences: Pyxiloricaria menezesi has a slightly lighter ground colour, a more acute, triangular head profile in dorsal view, longer and broader pectoral fins, larger eyes, a different colour pattern, and particularly the coalescing scutes in transverse section in a more vertical position. The abdominal scutelets in the Pseudohemiodon specimens of comparable size are different in size and pattern, covering most of the belly. The Pseudohemiodon specimens have a broader ossified ventral head margin, and a conspicuous ventrorostral extension. Moreover, the Pseudohemiodon specimens have different lips (lower lip papillate, without barbels; lip with numerous long, papillate barbels along the posterior margin), and lack the fleshy flap covering the branchiostegal membrane in Pyxiloricaria menezesi. Such a flap is not known to be present in any other loricariid.

\section{REFERENCES}

IsBrücker, I. J. H. H. NiJssen, 1978. Two new species and a new genus of neotropical mailed catfishes of the subfamily Loricariinae Swainson, 1838 (Pisces, Siluriformes, Loricariidae). Beaufortia, 27 (339): 177-206.

Martín Salazar, F. J., I. J. H. Isbrücker \& H. NijsSen, 1982. Dentectus barbarmatus, a new genus and species of mailed catfish from the Orinoco Basin of Venezuela (Pisces, Siluriformes, Loricariidae). Beaufortia, 32 (8): 125-137. 